\title{
Effect of the Cobalt Substitution on the Structure and Properties of the Layered Sodium Cobaltate Derivatives
}

\author{
Andrei Klyndyuk ${ }^{1, *}$, Natalie Krasutskaya ${ }^{1}$, Lyudmila Evseeva $^{2}$, Ekaterina Chizhova ${ }^{1}$, Svetlana Tanaeva $^{2}$ \\ ${ }^{1}$ Department of Physical and Colloid Chemistry, Belarusian State Technological University, Belarus Republic \\ ${ }^{2}$ Thermophysical Measurements Lab, Department of Thermophysics, A.V. Luikov Heat and Mass Transfer Institute of the National \\ Academy of Sciences of Belarus, Belarus Republic
}

Copyright (C) 2015 Horizon Research Publishing All rights reserved.

\begin{abstract}
Using solid-state reactions method the ceramic samples of $\mathrm{Na}_{0.89} \mathrm{Co}_{0.9} M_{0.1} \mathrm{O}_{2}(M=\mathrm{Sc}, \mathrm{Ti}, \mathrm{Cr}-\mathrm{Zn}$, $\mathrm{Mo}, \mathrm{W}, \mathrm{Pb}, \mathrm{Bi}$ ) solid solutions had been prepared, their lattice constants had been determined and their microstructure, thermal expansion, thermal conductivity, electrical conductivity and thermo-EMF had been measured, and their power factor and figure-of-merit values had been calculated. Effect of the cobalt substitution by other metals in the $\mathrm{Na}_{0.89} \mathrm{CoO}_{2}$ on the crystal structure and physicochemical and functional properties of its derivatives was analyzed. It was found that $\mathrm{Na}_{0.89} \mathrm{Co}_{0.9} M_{0.1} \mathrm{O}_{2}$ cobaltates are the $p$-type conductors, which linear thermal expansion coefficient (LTEC) values varied within $(1.24-2.05) \cdot 10^{-5} \mathrm{~K}^{-1}$. It was found that the best thermoelectric properties among the oxides studied possessed $\mathrm{Na}_{0.89} \mathrm{Co}_{0.9} \mathrm{Ni}_{0.1} \mathrm{O}_{2}$ and $\mathrm{Na}_{0.89} \mathrm{Co}_{0.9} \mathrm{Bi}_{0.1} \mathrm{O}_{2}$ solid solutions which power factor and figure-of-merit estimated values at $1100 \mathrm{~K}$ are equal to 0.919 and $0.660 \mathrm{~mW} /(\mathrm{m} \cdot \mathrm{K})$ and 1.12 and 0.83 respectively.
\end{abstract}

Keywords Layered Sodium Cobaltate, Thermoelectrics, Thermal Expansion, Thermal Conductivity, Electrical Conductivity, Thermo-EMF, Power Factor, Figure-of-Merit

\section{Introduction}

Heat which is released into environment during working of industrial factories and transport, can be effectively and directly converted into electrical energy using thermoelectric generators (TEG). To create TEG it is need to use so-called thermoelectrics - materials possessing high values of electrical conductivity and thermo-EMF coefficient and low values of thermal conductivity [1]. Such set of properties have bismuth $\left(\mathrm{Bi}_{2} \mathrm{Te}_{3}\right)$ and antimony tellurides $\left(\mathrm{Sb}_{2} \mathrm{Te}_{3}\right)$ and their solid solutions, skutterudites (for example, $\mathrm{Yb}_{y} \mathrm{Co}_{4} \mathrm{Sn}_{x} \mathrm{Sb}_{12-x}$ [2]), as well as silicides of iron and other metals $\left(\mathrm{FeSi}_{2}, \operatorname{Mg}(\mathrm{Si}, \mathrm{Ge})_{2}\right)$ [1, 3], which are used as materials for TEG and thermoelectric cooling batteries (TCB) since second half of the last century.
Classical thermoelectrics based on tellurides of heavy metals are characterized by high cost, high toxicity of the some components, and low stability at elevated temperatures in air, including possibility of their partial oxidation by atmospheric oxygen. The latter limits the usage of these materials at high temperature thermoelectric conversion.

Oxide thermoelectrics deprived of this deficiency [4], and their active investigation began after discovery of high thermoelectric efficiency in $\mathrm{NaCo}_{2} \mathrm{O}_{4}$ single crystals by Terasaki et al. in 1987 [5].

Layered sodium cobaltate $\mathrm{Na}_{x} \mathrm{CoO}_{2}$ is characterized by high values of electrical conductivity and thermo-EMF and low thermal conductivity [4-6], which allows us to consider it as prospective base for development of the new effective oxide thermoelectrics. To improve the functional (thermoelectric) parameters of materials based on it one can using solution methods of the synthesis $[7,8]$, spark plasma sintering [9] as well as by means of partial substitution of sodium ions [10] or cobalt ions in its structure by other metal ions [11-16].

Partial substitution of cobalt by copper in the $\mathrm{Na}_{0.5} \mathrm{Co}_{1-}$ ${ }_{x} \mathrm{Cu}_{x} \mathrm{O}_{2}$ ceramics improves its sinterability and increases its electrical conductivity $(\sigma)$ and thermo-EMF coefficient $(S)$ whereupon power factor $(P)$ values of the solid solutions rise in contrast to the unsubstituted phase reaching the maximal value for $\mathrm{Na}_{0.5} \mathrm{Co}_{0.9} \mathrm{Cu}_{0.1} \mathrm{O}_{2}-3.08 \mathrm{~mW} /\left(\mathrm{m} \cdot \mathrm{K}^{2}\right)$ at $1073 \mathrm{~K}$ temperature [11]. Substitution of cobalt by nickel deteriorates the sinterability and decreases electrical conductivity of $\mathrm{Na}_{0.5} \mathrm{Co}_{1-x} \mathrm{Ni}_{x} \mathrm{O}_{2}$ phases but leads to the increasing of their thermo-EMF coefficient, at that the $P$ value for $\mathrm{Na}_{0.5} \mathrm{Co}_{0.95} \mathrm{Ni}_{0.05} \mathrm{O}_{2}$ solid solution at $1073 \mathrm{~K}$ is equal to $2.36 \mathrm{~mW} /\left(\mathrm{m} \cdot \mathrm{K}^{2}\right)$ which is 8 times higher than for bases oxide $\mathrm{Na}_{0.5} \mathrm{CoO}_{2}$ [12]. Partial substitution of cobalt by zinc in $\mathrm{Na}_{0.5} \mathrm{Co}_{1-x} \mathrm{Zn}_{x} \mathrm{O}_{2}$ leads to the increasing of the $\sigma$ and $S$ values of ceramics and power factor value of $\mathrm{Na}_{0.5} \mathrm{Co}_{0.95} \mathrm{Zn}_{0.05} \mathrm{O}_{2}$ solid solution reaches $1.7 \mathrm{~mW} /\left(\mathrm{m} \cdot \mathrm{K}^{2}\right)$ at $1073 \mathrm{~K}$, which is 4 times higher than for unsubstituted sodium cobaltate $\mathrm{Na}_{x} \mathrm{CoO}_{2}$ [13].

In the works of $[14,15]$ at attempt of improving of thermoelectric properties of $\mathrm{Na}_{x} \mathrm{CoO}_{2}$ ceramics by means of 
substitution of cobalt by silver it was established that solubility of $\mathrm{Ag}_{2} \mathrm{O}$ in $\mathrm{Na}_{x} \mathrm{CoO}_{2}$ is small, that is why the $\mathrm{Na}_{x} \mathrm{Co}_{1-y} \mathrm{Ag}_{y} \mathrm{O}_{2}$ samples are microcomposites, which matrix is $\mathrm{Na}_{x}(\mathrm{Co}, \mathrm{Ag}) \mathrm{O}_{2}$ solid solution, but silver is allocated at the grain boundaries as $\mathrm{Ag}$ or $\mathrm{Ag}_{2} \mathrm{O}[15,16]$; functional characteristics of these composites are better than for basis oxide $\mathrm{Na}_{x} \mathrm{CoO}_{2}$ : figure-of-merit $(Z T)$ of ceramics at $973 \mathrm{~K}$ is equal to 0.04 and 0.12 for $\mathrm{Na}_{0.75} \mathrm{CoO}_{2}$ and $\mathrm{Na}_{0.75} \mathrm{Co}_{0.9} \mathrm{Ag}_{0.1} \mathrm{O}_{2}$ respectively [15], but power factor reaches the value of 0.687 $\mathrm{mW} /\left(\mathrm{m} \cdot \mathrm{K}^{2}\right)$ for the sample with composition of $\mathrm{Na}_{0.85} \mathrm{Co}_{0.9} \mathrm{Ag}_{0.1} \mathrm{O}_{2}$ [16].

It is known, that increasing of sodium content in the $\mathrm{Na}_{x} \mathrm{CoO}_{2}$ phases increases their power factor and figure-of-merit values [17, 18]. Further, analysis of the literature data shows that optimal substitution level of cobalt ions by other metal ions in $\mathrm{Na}_{x} \mathrm{CoO}_{2}$ is $5-10$ mol.\% but problem of the search of optimal substituents is still not solved.

To take part in the solving of such problem in this work the influence of the nature of different metal ions on the crystal structure, microstructure, physicochemical and functional (thermoelectric) properties of the $\mathrm{Na}_{0.89} \mathrm{Co}_{0.9} M_{\mathrm{O}}$ ( $M=\mathrm{Sc}, \mathrm{Ti}, \mathrm{Cr}-\mathrm{Zn}, \mathrm{Mo}, \mathrm{W}, \mathrm{Pb}, \mathrm{Bi})$ solid solutions was investigated.

\section{Materials and Methods}

The ceramic samples of the cobaltates with composition of $\mathrm{Na}_{0.89} \mathrm{Co}_{0.9} M_{0.1} \mathrm{O}_{2}(M=\mathrm{Sc}, \mathrm{Ti}, \mathrm{Cr}-\mathrm{Zn}, \mathrm{Mo}, \mathrm{W}, \mathrm{Pb}, \mathrm{Bi})$ were obtained using solid-state reactions method from $\mathrm{Na}_{2} \mathrm{CO}_{3}$ (pure for analysis grade), $\mathrm{Sc}_{2} \mathrm{O}_{3}$ (super pure grade), $\mathrm{TiO}_{2}$ (pure for analysis grade), $\mathrm{Cr}_{2} \mathrm{O}_{3}$ (pure for analysis grade), $\mathrm{Mn}_{2} \mathrm{O}_{3}$ (super pure grade), $\mathrm{Fe}_{2} \mathrm{O}_{3}$ (super pure grade), $\mathrm{Co}_{3} \mathrm{O}_{4}$ (pure grade), $\mathrm{NiO}$ (super pure grade), $\mathrm{CuO}$ (pure for analysis grade), $\mathrm{ZnO}$ (pure grade), $\mathrm{MoO}_{3}$ (pure grade), $\mathrm{WO}_{3}$ (pure grade), $\mathrm{PbO}$ (pure for analysis grade), and $\mathrm{Bi}_{2} \mathrm{O}_{3}$ (pure grade), which were taken in relation of $\mathrm{Na}: \mathrm{Co}: M=1.2$ : $0.9: 0.1$ (excess of $\mathrm{Na}_{2} \mathrm{CO}_{3}$ in the initial mixture compensates the losses of $\mathrm{Na}_{2} \mathrm{O}$ by the samples during their thermal treatment and allow us to obtain the ceramics of the predetermined composition [19]) in air within 1183-1233 K temperature interval.

Identification of the samples and determination of their lattice constants was performed using X-ray diffraction analysis (XRD) (Bruker D8 XRD Advance diffractometer, $\mathrm{CuK}_{\alpha}-$ radiation, $\mathrm{Ni}$ filter). On the base of XRD results the $\mathrm{X}$-ray density of the samples $\left(\rho_{\mathrm{XRD}}\right)$ values were calculated. IR-absorption spectra of the powder samples were recorded in the tablet mixtures with $\mathrm{KBr}$ (chemically pure grade) for the Nexus ThermoNicolet Fourier spectrometer in the frequency range $300-1500 \mathrm{~cm}^{-1}$. Microstucture of the sintered ceramics was studied using scanning electron microscope JSM-5610 LV. The apparent density $(\rho)$ of the samples was calculated using their mass and geometrical dimensions and porosity ( $\Pi)$ of the sintered ceramics was found using formula $\Pi=\left(1-\rho / \rho_{\text {XRD }}\right) \cdot 100 \%[20]$.
Thermal expansion, electrical conductivity and thermo-EMF coefficient of the samples were investigated in air within 300-1100 K temperature interval by methods described in $[19,21,22]$. Linear thermal expansion coefficient (LTEC, $\alpha$ ) values of the oxides studied were calculated from the linear parts of the $\Delta l / l_{0}=f(T)$ depencences. Values of power factor and figure-of-merit of the ceramics were calculated using formulae $P=S^{2} \cdot \sigma, Z T=$ $(P \cdot T) / \lambda$, where $\lambda$ is thermal conductivity of ceramics, $T$ is the absolute temperature $[4,23]$. Thermal conductivity of the samples was measured within 298-423 K temperature interval by means of thermal conductivity meter IT $-\lambda-400$. Lattice (phonon) $\left(\lambda_{\mathrm{ph}}\right)$ and electronic $\left(\lambda_{\mathrm{el}}\right)$ parts of thermal conductivity were found using relations of $\lambda=\lambda_{\mathrm{ph}}+\lambda_{\mathrm{el}}, \lambda_{\mathrm{el}}=$ $\sigma \cdot L \cdot T$, where $L$ is the Lorentz number $\left(L=2.45 \cdot 10^{-8} \mathrm{~W} \cdot \Omega \cdot \mathrm{K}^{-2}\right)$ [23].

\section{Results and Discussion}

After final stage of the synthesis all the $\mathrm{Na}_{0.89} \mathrm{Co}_{0 .} M_{0.1} \mathrm{O}_{2}$ solid solutions were, within XRD accuracy, monophase (Figure 1, lines 1-5), although on the IR absorption spectra of powders besides the absorption band of the main phase (layered sodium cobaltate) the bands of impurity phases $\left(\mathrm{Na}_{2} \mathrm{CO}_{3}\right.$ and $\left.\mathrm{Co}_{3} \mathrm{O}_{4}\right)$ were observed (Figure 1, lines 6-10), which are formed by partial degradation of the surface of powder particles due to their interaction with atmospheric $\mathrm{CO}_{2}$ according to reaction (1)

$$
\begin{gathered}
\mathrm{Na}_{x} \mathrm{CoO}_{2}+x / 2 \mathrm{CO}_{2} \rightarrow \\
\rightarrow x / 2 \mathrm{Na}_{2} \mathrm{CO}_{3}+1 / 3 \mathrm{Co}_{3} \mathrm{O}_{4}+(1 / 3-x / 4) \mathrm{O}_{2}
\end{gathered}
$$

The structure of the samples was hexagonal and corresponds to the structure of $\gamma-\mathrm{Na}_{x} \mathrm{CoO}_{2}$ [24], and values of their lattice constants varied within $a=2.813-2.836 \AA, c$ $=10.91-10.97 \AA, V=75.4-76.3 \AA^{3}$, which is close to the values of unsubstituted $\mathrm{Na}_{0.89} \mathrm{CoO}_{2}$ phase $(a=2.826 \AA, c=$ $10.93 \AA, V=75.6 \AA^{3}$ ) (Table 1). Value of the axial ratio (c/a) of $\mathrm{Na}_{0.89} \mathrm{Co}_{0.9} M_{0.1} \mathrm{O}_{2}$ solid solutions was equal to $3.85-$ 3.88 , which is also close to the characteristics of the base sodium cobaltate (for $\mathrm{Na}_{0.89} \mathrm{CoO}_{2} c / a=3.87$ ) (Table. 1). So, partial substitution of cobalt by other metals in $\mathrm{Na}_{0.89} \mathrm{CoO}_{2}$ do not lead to the essential changes of the size and form of the unit cell of solid solutions formed at this substitution in comparison to the unsubstituted phase.

On the IR absorption spectra of the $\mathrm{Na}_{0.89} \mathrm{Co}_{0.9} M_{0.1} \mathrm{O}_{2}$ powders the absorption bands with extrema at 561-575 $\mathrm{cm}^{-1}$ were observed (Figure 1, lines 6-10), which correspond to the vibrations of $(\mathrm{Co}, M)-\mathrm{O}$ bonds in the $-\left[(\mathrm{Co}, M) \mathrm{O}_{2}\right]-$ layers of their crystal structure [25] as well as the absorption bands of $\mathrm{Na}_{2} \mathrm{CoO}_{3}$ and $\mathrm{Co}_{3} \mathrm{O}_{4}$ impurity phases, which are formed, as it was mentioned above, due to the partial degradation of the surface of the powders particles due to their interaction with atmospheric carbon dioxide. Values of absorption extrema of the samples studied were close each other; so, partial substitution of cobalt by other metals in $\mathrm{Na}_{0.89} \mathrm{CoO}_{2}$ do not changed practically the energy of metal-oxygen interactions 
in its structure. It should be noted that IR-absorption spectroscopy results are in a good accordance with the XRD data which show that lattice constants of $\mathrm{Na}_{0.89} \mathrm{Co}_{0.9} M_{0.1} \mathrm{O}_{2}$ solid solutions are close to the lattice constants of unsubstituted sodium cobaltate $\mathrm{Na}_{0.89} \mathrm{CoO}_{2}$.

Values of X-ray density of the samples varied within 4.80 $5.56 \mathrm{~g} / \mathrm{cm}^{3}$ and increased regularly at partial substitution of cobalt by heavy metals (Mo, W, Pb, Bi) (Table 1).

The sizes of crystallites (values of coherent scattering area) $(t)$ of the samples, which was determined using
Debye-Sherrer equation

$$
t=(0.9 \lambda) /(\beta \cos \Theta)
$$

where $\lambda$ is wavelength, $\beta$ is width of reflex on its half of height, and $\Theta$ is the diffraction angle [26], are given in the Table 1. As can be seen, values of crystallites for $\mathrm{Na}_{0.89} \mathrm{Co}_{0.9} M_{0.1} \mathrm{O}_{2}$ solid solution are equal to $59-82 \mathrm{~nm}$ and are larger than for base sodium cobaltate $(50 \mathrm{~nm})$ (Table 1), and the maximal value of coherent scattering area possesses $\mathrm{Na}_{0.89} \mathrm{Co}_{0.9} \mathrm{Cu}_{0.1} \mathrm{O}_{2}$ solid solution $(82 \mathrm{~nm})$.

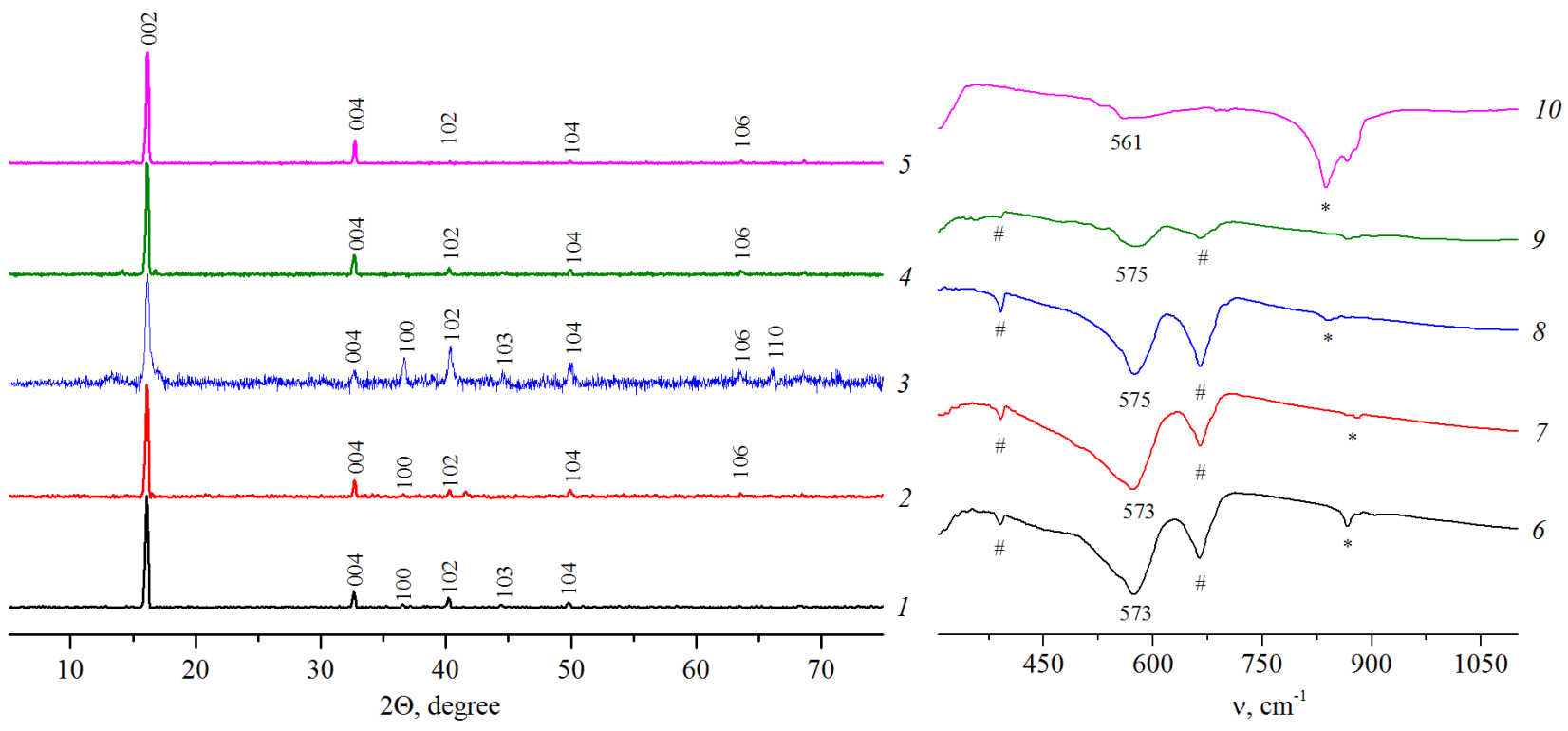

Figure 1. X-ray powder diffractograms ( $\mathrm{CuK}_{\alpha}$-radiation) (1-5) and IR-absorption spectra (6-10) of $\mathrm{Na}_{0.89} \mathrm{Co}_{0.1} M_{0.1} \mathrm{O}_{2}$ samples: $M=\mathrm{Ti}(1,6), \mathrm{Mn}(2,7)$, $\mathrm{Co}(3,8), \mathrm{Mo}(4,9)$, and $\mathrm{Pb}(5,10)$. Symbols \# and * depict the absorption bands of impurities $\mathrm{Co}_{3} \mathrm{O}_{4}$ and $\mathrm{Na}_{2} \mathrm{CO}_{3}$ respectively

Table 1. Lattice constants $(a, c, c / a, V)$, x-ray ( $\left.\rho_{\text {XRD }}\right)$ and apparent $(\rho)$ density as well as coherent scattering area $(t)$ of the $\mathrm{Na}_{0.89} \mathrm{Co}_{0.9} M_{0.1} \mathrm{O}_{2}$ solid solutions

\begin{tabular}{|c|c|c|c|c|c|c|c|}
\hline $\mathrm{M}$ & $a, \AA$ & $c, \AA$ & $c / a$ & $V, \AA^{3}$ & $\rho_{\text {XRD}}, \mathrm{g} / \mathrm{cm}^{3}$ & $\rho, \mathrm{g} / \mathrm{cm}^{3}$ & $t, \mathrm{~nm}$ \\
\hline $\mathrm{Sc}$ & $2.828(3)$ & $10.91(2)$ & 3.86 & $75.6(3)$ & 4.83 & 2.82 & 71 \\
\hline $\mathrm{Ti}$ & $2.836(3)$ & $10.96(2)$ & 3.87 & $76.3(3)$ & 4.80 & 3.05 & 66 \\
\hline $\mathrm{Cr}$ & $2.828(9)$ & $10.93(2)$ & 3.87 & $75.7(4)$ & 4.86 & 3.18 & 59 \\
\hline $\mathrm{Mn}$ & $2.813(3)$ & $10.96(2)$ & 3.87 & $76.1(3)$ & 4.87 & 2.87 & 66 \\
\hline $\mathrm{Fe}$ & $2.827(4)$ & $10.96(2)$ & 3.88 & $75.8(4)$ & 4.89 & 2.94 & 66 \\
\hline $\mathrm{Co}$ & $2.826(3)$ & $10.93(1)$ & 3.87 & $75.6(2)$ & 4.98 & 3.04 & 50 \\
\hline $\mathrm{Ni}$ & $2.834(3)$ & $10.91(7)$ & 3.85 & $75.9(3)$ & 4.88 & 3.46 & 74 \\
\hline $\mathrm{Cu}$ & $2.821(3)$ & $10.93(2)$ & 3.88 & $75.4(3)$ & 4.93 & 3.23 & 82 \\
\hline $\mathrm{Zn}$ & $2.826(24)$ & $10.94(14)$ & 3.87 & $75.7(2)$ & 4.92 & 3.26 & 67 \\
\hline $\mathrm{Mo}$ & $2.823(3)$ & $10.96(19)$ & 3.88 & $75.6(3)$ & 5.06 & 3.22 & 71 \\
\hline $\mathrm{W}$ & $2.825(4)$ & $10.97(23)$ & 3.88 & $75.8(3)$ & 5.43 & 3.20 & 66 \\
\hline $\mathrm{Pb}$ & $2.824(3)$ & $10.92(19)$ & 3.87 & $75.5(3)$ & 5.55 & 3.34 & 66 \\
\hline $\mathrm{Bi}$ & $2.822(2)$ & $10.95(39)$ & 3.88 & $75.5(4)$ & 5.56 & 3.47 & 71 \\
\hline
\end{tabular}


Table 2. Porosity $(\Pi)$, linear thermal expansion coefficient $(\alpha)$, electrical conductivity $\left(\sigma_{T}\right)$, thermo-EMF coefficient $\left(S_{T}\right)$, power factor $\left(P_{T}\right)$, thermal conductivity $\left(\lambda_{T}\right)$, and figure-of-merit $\left(Z T_{T}\right)$ of $\mathrm{Na}_{0.89} \mathrm{Co}_{0.9} M_{0.1} \mathrm{O}_{2}$ ceramics

\begin{tabular}{|c|c|c|c|c|c|c|c|c|}
\hline $\mathrm{M}$ & $\Pi, \%$ & $10^{5} \cdot \alpha, \mathrm{K}^{-1}$ & $\sigma_{1100}, \mathrm{kS} / \mathrm{m}$ & $S_{1100}, \mathrm{mV} / \mathrm{K}$ & $P_{1100}, \mathrm{~mW} /\left(\mathrm{m} \cdot \mathrm{K}^{2}\right)$ & $\lambda_{423}, \mathrm{~W} /(\mathrm{m} \cdot \mathrm{K})$ & $Z T_{423}$ & $Z T_{1100}$ \\
\hline $\mathrm{Sc}$ & 42 & 1.48 & 1.46 & 0.161 & 0.038 & - & - & - \\
\hline $\mathrm{Ti}$ & 36 & 1.75 & 0.52 & 0.376 & 0.074 & - & - & - \\
\hline $\mathrm{Cr}$ & 35 & 1.68 & 3.08 & 0.138 & 0.059 & - & - & - \\
\hline $\mathrm{Mn}$ & 41 & 1.68 & 0.97 & 0.403 & 0.157 & - & - & - \\
\hline $\mathrm{Fe}$ & 40 & 2.05 & 0.79 & 0.127 & 0.013 & - & - & - \\
\hline $\mathrm{Co}$ & 28 & 1.34 & 4.11 & 0.303 & 0.421 & 0.82 & 0.05 & 0.56 \\
\hline $\mathrm{Ni}$ & 29 & 1.42 & 6.60 & 0.373 & 0.919 & 0.90 & 0.22 & 1.12 \\
\hline $\mathrm{Cu}$ & 34 & 1.24 & 6.08 & 0.318 & 0.615 & 0.89 & 0.10 & 0.76 \\
\hline $\mathrm{Zn}$ & 34 & 1.36 & 1.36 & 0.365 & 0.181 & - & - & - \\
\hline $\mathrm{Mo}$ & 36 & 1.47 & 1.83 & 0.406 & 0.302 & 0.96 & 0.04 & 0.35 \\
\hline $\mathrm{W}$ & 41 & 1.39 & 1.26 & 0.600 & 0.454 & - & - & - \\
\hline $\mathrm{Pb}$ & 40 & 1.26 & 1.77 & 0.363 & 0.231 & - & - & - \\
\hline $\mathrm{Bi}$ & 38 & 1.25 & 1.69 & 0.625 & 0.660 & 0.87 & 0.07 & 0.83 \\
\hline
\end{tabular}
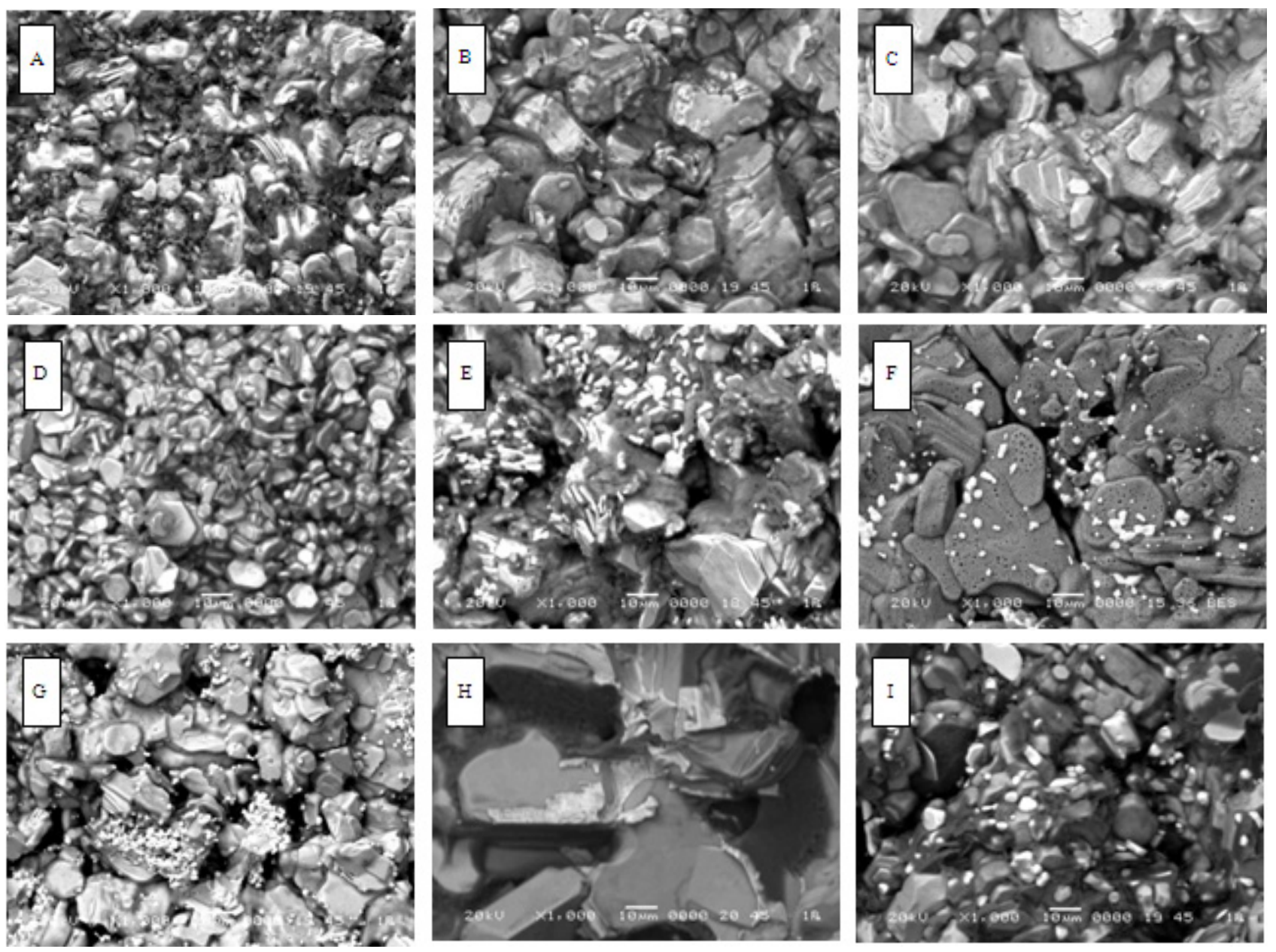

Figure 2. Electron micrographs of $\mathrm{Na}_{0.89} \mathrm{Co}_{0.9} M_{0.1} \mathrm{O}_{2}$ ceramic cleavages: $M=\mathrm{Sc}(\mathrm{A}), \mathrm{Ti}(\mathrm{B}), \mathrm{Cr}(\mathrm{C}), \mathrm{Mn}(\mathrm{D}), \mathrm{Fe}(\mathrm{E}), \mathrm{Co}(\mathrm{F}), \mathrm{Ni}(\mathrm{G}), \mathrm{Cu}(\mathrm{H})$, and $\mathrm{Zn}(\mathrm{I})$

Apparent density of the sintered ceramics varied within $4.80-5.56 \mathrm{~g} / \mathrm{cm}^{3}$ (Table 1) decreasing at substitution of cobalt by other $3 d$-metals ( $\mathrm{Sc}, \mathrm{Ti}, \mathrm{Cr}-\mathrm{Zn}$ ) and increasing at substitution of cobalt by $4 d$ - (Mo), $5 d$ - (W) and $6 p$-metals $(\mathrm{Pb}, \mathrm{Bi})$. Values of porosity of the $\mathrm{Na}_{0.89} \mathrm{Co}_{0.9} M_{0.1} \mathrm{O}_{2}$ samples (29-42\%) were less than for $\mathrm{Na}_{0.89} \mathrm{CoO}_{2}(28 \%)$ (Table 2), which implies that partial substitution of cobalt by other metals in $\mathrm{Na}_{0.89} \mathrm{CoO}_{2}$ deteriorates sinterability of its derivatives.

As can be seen from the Figure 2, the grains of $\mathrm{Na}_{0.89} \mathrm{Co}_{0.9} M_{0.1} \mathrm{O}_{2}$ ceramics were anisometric and plate-like with thickness of $1-10 \mu \mathrm{m}$ and width of $8-50 \mu \mathrm{m}$. The form of the grains was close to hexagonal which is characteristic for hexagonal sodium cobaltate. According to 
the XRD results the crystallites sizes of $\mathrm{Na}_{0.89} \mathrm{Co}_{0.9} M_{0.1} \mathrm{O}_{2}$ cobaltates varied within 50-82 nm (Table 1); so, the grains of the ceramics were polycrystalline and contained more than million crystallites. It is interesting to note that habitus and grain size of the ceramics significantly changed when the nature of $3 d$-metals substituting cobalt in $\mathrm{Na}_{0.89} \mathrm{CoO}_{2}$ changed. For example, the $\mathrm{Na}_{0.89} \mathrm{Co}_{0.9} \mathrm{Mn}_{0.1} \mathrm{O}_{2}$ ceramic grains had the smallest size and shape of thin plates (Figure 2, D), whereas $\mathrm{Na}_{0.89} \mathrm{Co}_{0.9} M_{0.1} \mathrm{O}_{2}(M-\mathrm{Ti}, \mathrm{Cr}, \mathrm{Cu})$ ceramics consisted of relatively large grains having shape of the thick plates (Figure 2, B, C, H). Thus, the microstructure of ceramics based on the layered sodium cobaltate can be effectively controlled by addition different transition metal oxides to the samples.

Temperature dependences of the relative elongation of $\mathrm{Na}_{0.89} \mathrm{Co}_{0.9} M_{0.1} \mathrm{O}_{2}$ ceramic samples were linear practically; so, we can conclude that within temperature interval studied these compounds do not undergo any structural phase transitions. LTEC values of the $\mathrm{Na}_{0.89} \mathrm{Co}_{0.9} M_{0.1} \mathrm{O}_{2}$ solid solutions varied within $(1.24-2.05) \cdot 10^{-5} \mathrm{~K}^{-1}$ and, excluding
$\mathrm{Na}_{0.89} \mathrm{Co}_{0.9} \mathrm{Cu}_{0.1} \mathrm{O}_{2}, \mathrm{Na}_{0.89} \mathrm{Co}_{0.9} \mathrm{~Pb}_{0.1} \mathrm{O}_{2}$ and $\mathrm{Na}_{0.89} \mathrm{Co}_{0.9} \mathrm{Bi}_{0.1} \mathrm{O}_{2}$ cobaltates, were larger than for unsubstituted sodium cobaltate $\mathrm{Na}_{0.89} \mathrm{CoO}_{2}\left(1.34 \cdot 10^{-5} \mathrm{~K}^{-1}\right)$ (Table 2).

Obtained increasing of LTEC values of $\mathrm{Na}_{0.89} \mathrm{Co}_{0.9} M_{0.1} \mathrm{O}_{2}$ derivatives in comparison to the $\mathrm{Na}_{0.89} \mathrm{CoO}_{2}$ base phase, by our opinion, is due to the high values of their porosity (Table 2) as well as to the increasing of anharmonicity degree of metal-oxygen vibrations in their structure at partial substitution of cobalt by other metals.

As can be seen from the Figure 3, A, D, electrical conductivity of $\mathrm{Na}_{0.89} \mathrm{CoO}_{2}$ and its $\mathrm{Na}_{0.89} \mathrm{Co}_{0.9} M_{0.1} \mathrm{O}_{2}$ derivatives has metallic character $(\partial \sigma / \partial T<0)$, which for $\mathrm{Na}_{0.89} \mathrm{Co}_{0.9} \mathrm{Mo}_{0.1} \mathrm{O}_{2}, \quad \mathrm{Na}_{0.89} \mathrm{Co}_{0.9} \mathrm{~Pb}_{0.1} \mathrm{O}_{2}, \quad$ and $\mathrm{Na}_{0.89} \mathrm{Co}_{0.9} \mathrm{Bi}_{0.1} \mathrm{O}_{2}$ solid solutions at high temperatures $(T>$ 800-900 K) changes to semiconducting $(\partial \sigma / \partial T<0)$ (excluding $\mathrm{Na}_{0.89} \mathrm{Co}_{0.9} \mathrm{~W}_{0.1} \mathrm{O}_{2}$, which electrical conductivity within all the temperature interval studied has semiconducting character, and $\mathrm{Na}_{0.89} \mathrm{Co}_{0.9} \mathrm{Fe}_{0.1} \mathrm{O}_{2}$, which electrical conductivity value did not depend on the temperature practically).
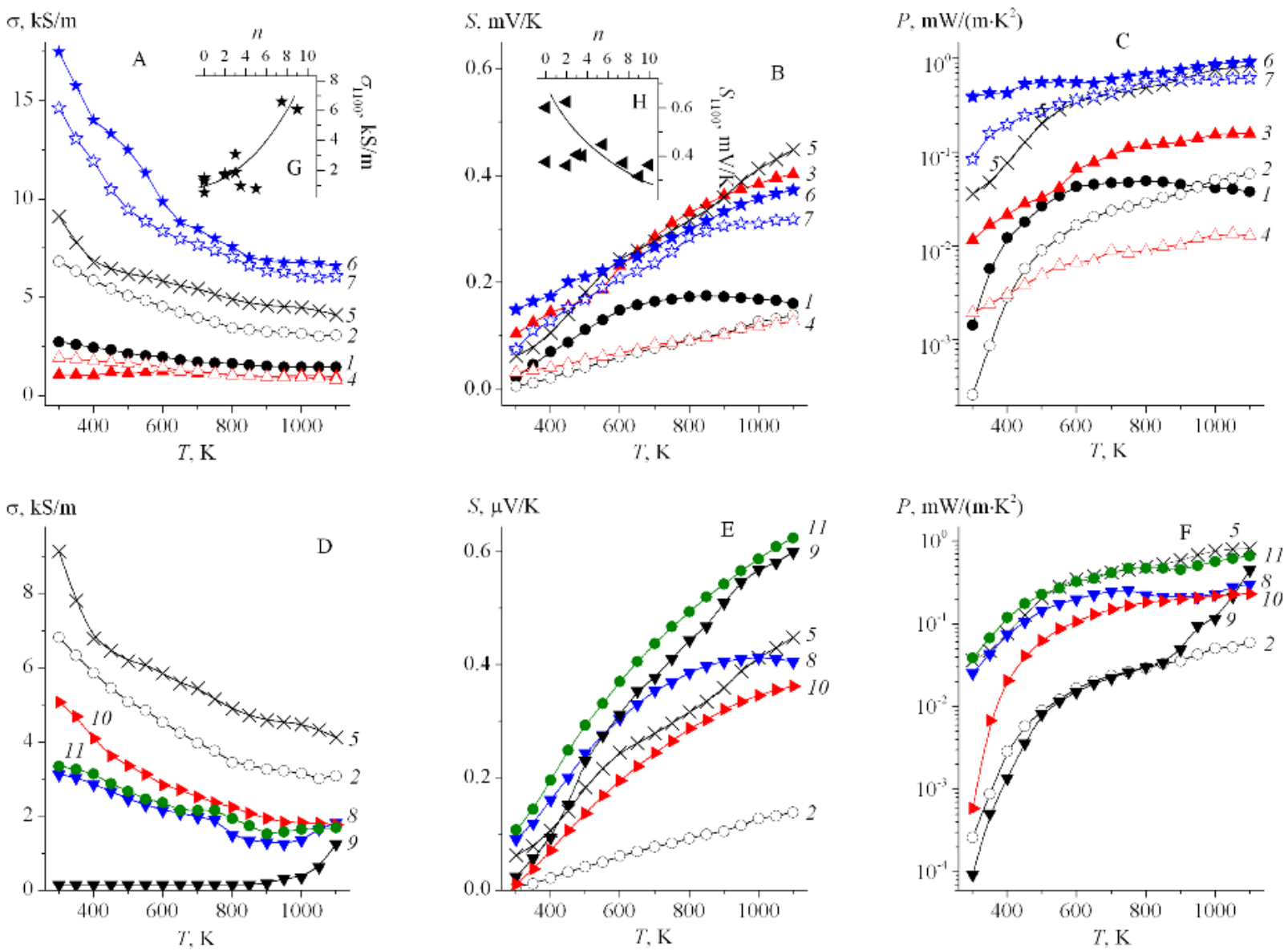

Figure 3. Temperature dependences of electrical conductivity $(\sigma)(\mathrm{A}, \mathrm{D})$, thermo-EMF coefficient $(S)(\mathrm{B}, \mathrm{E})$, and power factor $(P)(\mathrm{C}, \mathrm{F})$ of $\mathrm{Na}_{0.89} \mathrm{Co}_{0.9} M_{0.1} \mathrm{O}_{2}$ sintered ceramics: $M=\mathrm{Sc}(1), \mathrm{Cr}$ (2), Mn (3), Fe (4), Co (5), Ni (6), Cu (7), Mo (8), W (9), Pb (10), and Bi (11). Insets: dependences of electrical conductivity $\left(\sigma_{1100}\right)(\mathrm{G})$, thermo-EMF coefficient $\left(S_{1100}\right)(\mathrm{H})$ on the number of electrons $(n)$ on the external electron shell of metal cations substituting cobalt cations in $\mathrm{Na}_{0.89} \mathrm{CoO}_{2}$ phase 
Herewith, electrical conductivity values of the samples, in the whole, decreased at increasing oxidation degree of metals substituting cobalt in $\mathrm{Na}_{0.89} \mathrm{CoO}_{2}$ $\left(\sigma\left(\mathrm{Na}_{0.89} \mathrm{Co}_{0.9} \mathrm{Cu}_{0.1} \mathrm{O}_{2}\right)>\sigma\left(\mathrm{Na}_{0.89} \mathrm{CoO}_{2}\right)>\sigma\left(\mathrm{Na}_{0.89} \mathrm{Co}_{0.9} \mathrm{Bi}_{0.1} \mathrm{O}_{2}\right)\right)$ (Figure 3, A, D, Table 2), which are in good agreement with the results of [11-13] and can be explained by decreasing of concentration of main charge carriers ("holes") in the layered sodium cobaltate derivatives at increasing of average oxidation degree of cations in the conducting $-\left[(\mathrm{Co}, M) \mathrm{O}_{2}\right]-$ layers of the crystal structure of $\mathrm{Na}_{0.89} \mathrm{Co}_{0.9} M_{0.1} \mathrm{O}_{2}$ phases.

Values of thermo-EMF coefficient of the $\mathrm{Na}_{0.89} \mathrm{Co}_{0.9} M_{0.1} \mathrm{O}_{2}$ increased at temperature increasing and, in the whole, at increasing of oxidation degree of metal substituting cobalt in $\mathrm{Na}_{0.89} \mathrm{CoO}_{2}$ (Figure 3, B, E, Table 2), which is typical for common conductors, for which increasing of concentration of main charge carriers leads to the increasing of electrical conductivity values and decreasing of their thermo-EMF coefficient. At the same time, $S$ values of $\mathrm{Na}_{0.89} \mathrm{Co}_{0.9} \mathrm{Ni}_{0.1} \mathrm{CoO}_{2}, \mathrm{Na}_{0.89} \mathrm{Co}_{0.9} \mathrm{Cu}_{0.1} \mathrm{O}_{2}$, $\mathrm{Na}_{0.8} \mathrm{Co}_{0.9} \mathrm{~W}_{0.1} \mathrm{O}_{2}$, and $\mathrm{Na}_{0.89} \mathrm{Co}_{0.9} \mathrm{Bi}_{0.1} \mathrm{O}_{2}$ were abnormally larger than for $\mathrm{Na}_{0.89} \mathrm{CoO}_{2}$, which cannot be explained in the frame of quasi-chemical approach.

It is known, that electronic subsystem of layered sodium cobaltate $\mathrm{Na}_{x} \mathrm{CoO}_{2}$ and its derivatives is strongly correlated, and value of their thermo-EMF coefficient described using modificated Heikes's equation

$$
S=(k / e) \ln \left[\left(g_{4}\left[\mathrm{Co}^{3+}\right]\right) /\left(g_{3}\left[\mathrm{Co}^{4+}\right]\right)\right],
$$

where $k$ is the Boltzmann's constant, $e$ is charge of electron, $g_{4}$ and $g_{3}$ are degeneracy of $\mathrm{Co}^{4+}$ and $\mathrm{Co}^{3+}$ ions respectively, $\left[\mathrm{Co}^{3+}\right]$ and $\left[\mathrm{Co}^{4+}\right]$ are concentration's of $\mathrm{Co}^{3+}$ and $\mathrm{Co}^{4+}$ ions in conducting $-\left[\mathrm{CoO}_{2}\right]-$ layers of $\mathrm{Na}_{x} \mathrm{CoO}_{2}$ crystal structure [27].

So, thermo-EMF coefficient of $\mathrm{Na}_{0.89} \mathrm{Co}_{0.9} M_{0.1} \mathrm{CoO}_{2}$ is determined both ratio of concentrations of $\left.\left[\mathrm{Co}^{3+}\right]\right) /\left[\mathrm{Co}^{4+}\right]$, which depends on oxidation degree of metals substituting

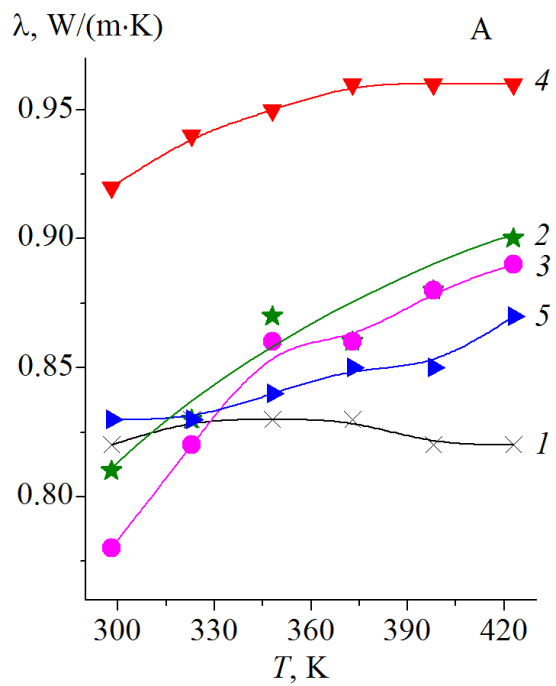

cobalt in $\mathrm{Na}_{0.89} \mathrm{CoO}_{2}$, and ratio of degeneracy's $g_{4} / g_{3}$, which depends on spin states of cobalt ions $\mathrm{Co}^{3+}, \mathrm{Co}^{4+}$ and metal-substituent $M^{z^{+}}$. As can be seen from the Figure 3, G, $\mathrm{H}$, electrical conductivity $\mathrm{Na}_{0.89} \mathrm{Co}_{0.9} M_{0.1} \mathrm{CoO}_{2}$ cobaltates increases, but thermo-EMF coefficient decreases at increasing of number of electrons on the external electron shell of metal cation $M^{z^{+}}$substituting cobalt cations in $\mathrm{Na}_{0.89} \mathrm{CoO}_{2}$. So, we can conclude, that electrotransport properties of the $\mathrm{Na}_{0.89} \mathrm{Co}_{0.9} M_{0.1} \mathrm{CoO}_{2}$ solid solutions are determined both charge and spin states of cations in the conducting $-\left[(\mathrm{Co}, M) \mathrm{O}_{2}\right]-$ layers of their crystal structure.

This is in a good accordance with the conclusions, which had been done by authors of [27] at analysis of concentration dependence of thermo-EMF coefficient of $\mathrm{Na}_{x} \mathrm{CoO}_{2}$ cobaltates with varying sodium content.

Power factor values of $\mathrm{Na}_{0.89} \mathrm{Co}_{0.9} M_{0.1} \mathrm{O}_{2}$ sintered ceramics increased at temperature increasing and nonmonotonously changed at changing of the nature of metal substituting cobalt in $\mathrm{Na}_{0.89} \mathrm{CoO}_{2}$ (Figure 3, C, F, Table 2), reaching the maximal values for $\mathrm{Na}_{0.89} \mathrm{Co}_{0.9} \mathrm{Ni}_{0.1} \mathrm{O}_{2}$, $\mathrm{Na}_{0.89} \mathrm{Co}_{0.9} \mathrm{Bi}_{0.1} \mathrm{O}_{2}$, and $\mathrm{Na}_{0.89} \mathrm{Co}_{0.9} \mathrm{Cu}_{0.1} \mathrm{O}_{2}$ solid solutions $0.919,0.660$, and $0.615 \mathrm{~mW} /\left(\mathrm{m} \cdot \mathrm{K}^{2}\right)$ respectively, which is 2.18, 1.57, and 1.46times larger, than for unsubstituted layered sodium cobaltate $\mathrm{Na}_{0.89} \mathrm{CoO}_{2}$, and determined, mainly, by the high values of their thermo-EMF coefficient values.

As it seen from the data, which are given on the Figure 4, $\mathrm{A}$, and in the Table 2, values of thermal conductivity of ceramics studied within 298-423 K temperature interval, were, in the whole, close to each other, and varied within 0.78-0.96 W/ $(\mathrm{m} \cdot \mathrm{K})$, and for the $\mathrm{Na}_{0.89} \mathrm{Co}_{0.9} M_{0.1} \mathrm{O}_{2}$ solid solutions were larger (for $\mathrm{Na}_{0.89} \mathrm{Co}_{0.9} \mathrm{Ni}_{0.1} \mathrm{O}_{2}$ and $\mathrm{Na}_{0.89} \mathrm{Co}_{0.9} \mathrm{Cu}_{0.1} \mathrm{O}_{2}$ samples at $T<310-320 \mathrm{~K}$ less), than for unsubstituted sodium cobaltate $\mathrm{Na}_{0.89} \mathrm{CoO}_{2}$.

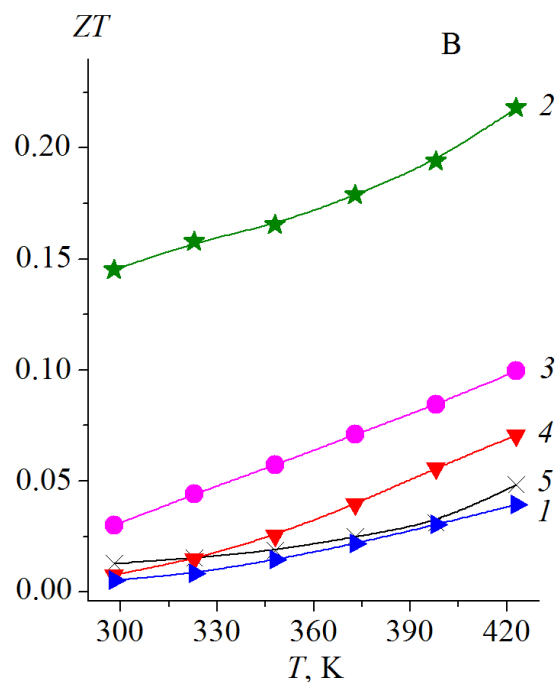

Figure 4. Temperature dependences of thermal conductivity ( $\lambda$ ) (A) and figure-of-merit $(Z T)$ (B) of $\mathrm{Na}_{0.89} \mathrm{Co}_{0.9} M_{0.1} \mathrm{O}_{2}$ cobaltates: $M=\mathrm{Co}(1), \mathrm{Ni}(2), \mathrm{Cu}$ (3), Mo (4), and Bi (5) 
Value of thermal conductivity of $\mathrm{Na}_{0.89} \mathrm{CoO}_{2}$ slightly varied, but $\mathrm{Na}_{0.89} \mathrm{Co}_{0.9} M_{0.1} \mathrm{O}_{2}(M-\mathrm{Ni}, \mathrm{Cu}, \mathrm{Mo}, \mathrm{Bi})$ solid solutions increased at temperature increasing (Figure 4, A). Electronic part of thermal conductivity of cobaltates studied was small $\left(\lambda_{\mathrm{el}} / \lambda \approx 0.03-0.16\right)$ and, in the whole, increased at temperature increasing. So, main part of heat transferred through the $\mathrm{Na}_{0.89} \mathrm{Co}_{0.9} M_{0.1} \mathrm{O}_{2}$ phases by means of lattice vibrations (phonons) $\left(\lambda_{\mathrm{ph}} \approx(0.84-0.98) \lambda\right)$.

Dimensionless figure-of-merit $(Z T)$ of $\mathrm{Na}_{0.89} \mathrm{Co}_{0.9} M_{0.1} \mathrm{O}_{2}$ cobaltates within 298-423 K temperature interval increased at increasing of temperature (Figure 4, B) and reached maximal values for $\mathrm{Na}_{0.89} \mathrm{Co}_{0.9} \mathrm{Ni}_{0.1} \mathrm{O}_{2}$, and $\mathrm{Na}_{0.89} \mathrm{Co}_{0.9} \mathrm{Cu}_{0.1} \mathrm{O}_{2}-0.22$, and 0.10 respectively at $423 \mathrm{~K}$, which was 4.4 and 2.0 times larger, than for $\mathrm{Na}_{0.89} \mathrm{CoO}_{2}$ cobaltate $(0.05)$ at the same temperature (Table 2). In the Table 2 are given also estimated values of $Z T_{1100}$ for $\mathrm{Na}_{0.89} \mathrm{Co}_{0.9} M_{0.1} \mathrm{O}_{2}$ ceramics, calculated using equation of $Z T_{1100}=\left(P_{1100} \cdot 1100\right) / \lambda_{423}$ (taking into account the weak dependence of thermal conductivity of ceramics obtained in this work on the temperature). As it seen, the best thermoelectric performance at $1100 \mathrm{~K}$ are expected for $\mathrm{Na}_{0.89} \mathrm{Co}_{0.9} \mathrm{Ni}_{0.1} \mathrm{O}_{2}$ and $\mathrm{Na}_{0.89} \mathrm{Co}_{0.9} \mathrm{Bi}_{0.1} \mathrm{O}_{2}$ samples, which estimated values of $Z T_{1100}$ are equal to 1.12 and 0.83 respectively. That is 2.0 and 1.5 times larger, than for unsubstituted sodium cobaltate $\mathrm{Na}_{0.89} \mathrm{CoO}_{2}(0.56)$ and is close to the theoretical criteria $(Z T>1$ [1]), determining materials, which are in interest for the practical thermoelectric conversion.

\section{Conclusions}

By means of the solid-state reactions method the $\mathrm{Na}_{0.89} \mathrm{Co}_{0.9} M_{0.1} \mathrm{O}_{2}(M=\mathrm{Sc}, \mathrm{Ti}, \mathrm{Cr}-\mathrm{Zn}, \mathrm{Mo}, \mathrm{W}, \mathrm{Pb}, \mathrm{Bi})$, cobaltates solid solutions were prepared, their crystal structure, microstructure, thermophisical, electrophysical and thermoelectric (functional) properties were studied. It was found, that $\mathrm{Na}_{0.89} \mathrm{Co}_{0.9} M_{0.1} \mathrm{O}_{2}$ cobaltates are $p$-type conductors, which LTEC values varied within (1.24 $2.05) \cdot 10^{-5} \mathrm{~K}^{-1}$. The influence of the nature of metal substituting cobalt in $\mathrm{Na}_{0.89} \mathrm{CoO}_{2}$ on the lattice constants, shape and size of the grains of $\mathrm{Na}_{0.89} \mathrm{Co}_{0.9} M_{0.1} \mathrm{O}_{2}$ ceramics, values of its electrical conductivity and thermo-EMF was analyzed. It was shown, that doping of $\mathrm{Na}_{0.89} \mathrm{CoO}_{2}$ sodium cobaltate by other metal oxides let us improve thermoelectric parameters of the solid solutions forming at this doping. So, power factor of $\mathrm{Na}_{0.89} \mathrm{Co}_{0.9} \mathrm{Ni}_{0.1} \mathrm{O}_{2}, \quad \mathrm{Na}_{0.89} \mathrm{Co}_{0.9} \mathrm{Bi}_{0.1} \mathrm{O}_{2}$, $\mathrm{Na}_{0.89} \mathrm{Co}_{0.9} \mathrm{Cu}_{0.1} \mathrm{O}_{2}$, and $\mathrm{Na}_{0.89} \mathrm{CoO}_{2}$ at $1100 \mathrm{~K}$ is equal to $0.919,0.660,0.615$, and $0.421 \mathrm{~mW} /\left(\mathrm{m} \cdot \mathrm{K}^{2}\right)$ respectively, dimensionless figure-of-merit of $\mathrm{Na}_{0.89} \mathrm{Co}_{0.9} \mathrm{Ni}_{0.1} \mathrm{O}_{2}$, $\mathrm{Na}_{0.89} \mathrm{Co}_{0.9} \mathrm{Cu}_{0.1} \mathrm{O}_{2}$ and $\mathrm{Na}_{0.89} \mathrm{CoO}_{2}$ at $423 \mathrm{~K}$ is equal to 0.056 , $0.22,0.10$, and 0.05 respectively, and its estimated values at $1100 \mathrm{~K}$ for $\mathrm{Na}_{0.89} \mathrm{Co}_{0.9} \mathrm{Ni}_{0.1} \mathrm{O}_{2}$ and $\mathrm{Na}_{0.89} \mathrm{Co}_{0.9} \mathrm{Bi}_{0.1} \mathrm{O}_{2}$ cobaltates are equal to 1.12 and 0.83 respectively, which is 2.0 and 1.5 times larger, than for $\mathrm{Na}_{0.89} \mathrm{CoO}_{2}\left(Z T_{1100}=0.56\right)$, and let us consider the $\mathrm{Na}_{0.89} \mathrm{CoO}_{2}$ derivatives as prospective materials for the high-temperature thermoelectric conversion.

\section{Acknowledgements}

This work was carried out in the frame of SSIP «Functional and engineering materials, nanomaterials» (subprogram «Crystal and molecular structures», task 1.23) and by partial financial support of Belarusian Republican Foundation for Fundamental Research (grant X12M-039).

\section{REFERENCES}

[1] D.M. Rowe (ed.). CRC Handbook of thermoelectrics. CRC Press, Boca Raton, FL, 1995.

[2] N.R. Dilley, E.D. Bauer, M.B. Maple, B.C. Sales. Thermoelectric properties of chemically substituted skutterudites $\mathrm{Yb}_{y} \mathrm{Co}_{4} \mathrm{Sn}_{x} \mathrm{Sb}_{12-x}$, J. Appl. Phys., Vol. 88, 1948-1951, 2000.

[3] O. Yamashita, S. Tomiyoshi, N. Sadatomi. Thermoelectric properties of $p$ - and $n$-type $\mathrm{FeSi}_{2}$ prepared by spray drying compaction and sintering technique, J. Mater. Sci., Vol. 38, 1623-1629, 2003.

[4] K. Koumoto, I. Terasaki, N. Murayama (eds.). Oxide Thermoelectrics. Research Signpost, Trivandrum, India, Research Signpost, 2002.

[5] I. Terasaki, Y. Sasago, K. Uchinokuraю Large thermoelectric power in $\mathrm{NaCo}_{2} \mathrm{O}_{4}$ single crystals, Phys. Rev. B., Vol. 56, No. 20, R12685-R12687, 1997-II.

[6] I. Terasaki. Novel Physics and Functions in the Layered Cobalt Oxides from Thermoelectricity to Ferromagnetism, Phys. B., 2006, Vol. 383, 107-110, 2006.

[7] M. Ito, T.Nagira, D. Furumoto, S.Katsuyama, H.Nagai. Synthesis of $\mathrm{Na}_{x} \mathrm{CoO}_{2}$ thermoelectric oxides by the polymerized complex method, Scripta Materialia, Vol. 48, 403-408, 2003.

[8] C.-J. Liu, J.-Y.Liao, T.-W.Wu, B.-Y.Jen. Preparation and transport properties of aqueous sol-gel synthesized $\mathrm{NaCo}_{2} \mathrm{O}_{4-\delta}, \mathrm{J}$. Mater. Sci., Vol. 39, 4569-4573, 2004

[9] I. Matsubara, Y. Zhou, T. Takeuchi, R. Funahashi, M. Shikano, N. Murayama, W. Shin, N. Izu. Thermoelectric Properties of Spark-Plasma-Sintered $\mathrm{Na}_{1+x} \mathrm{Co}_{2} \mathrm{O}_{4}$ ceramics, J. Ceram. Soc. Jap., Vol. 111 [4], 238-241, 2003.

[10] X. Yang, X. Wang, J. Liu, Z. Hu. Power factor enhancement in $\mathrm{Na}_{x} \mathrm{CoO}_{2}$ doped by Bi, J. Alloys Compd., Vol. 582, 59-63, 2014.

[11] K. Park, K.U. Jang, H.-C. Kwon, J.-C. Kim, W.S. Cho. Influence of Partial Substitution of $\mathrm{Cu}$ for $\mathrm{Co}$ on the Thermoelectric Properties of $\mathrm{NaCo}_{2} \mathrm{O}_{4}$, J. Alloys Compd., Vol. 419, 213-219, 2006

[12] K. Park, K.U. Jang. Improvement in High-Temperature Properties of $\mathrm{NaCo}_{2} \mathrm{O}_{4}$ through Partial Substitution of $\mathrm{Ni}$ for Co, Mater. Lett., Vol. 60, 1106-1110, 2006.

[13] K.Park, J.H.Lee. Enhanced Thermoelectric Properties of $\mathrm{NaCo}_{2} \mathrm{O}_{4}$ by Adding Z, Mater. Lett., Vol. 62, 2366-2368, 2008.

[14] T. Seetawan, V. Amornkitbamrung, T. Burinprakhon, S. 
Maensiri, K. Kurosaki, H. Muta, M. Uno, S. Yamanaka Thermoelectric Power and Electric Resistivity of Ag-Doped $\mathrm{Na}_{1.5} \mathrm{Co}_{2} \mathrm{O}_{4}$, J. Alloys Compd., Vol. 407, 314-317, 2006.

[15] T. Seetawan. Thermoelectric Properties of $\mathrm{Na}_{x} \mathrm{Co}_{2} \mathrm{O}_{4}$ with $\mathrm{Ag}$ Additions, J. of Thermoelectricity, No. 2, 17-23, 2006.

[16] N. Li, Y. Jiang, G. Li, S. Jianfeng, D. Yu.. Self-Ignition Route to $\mathrm{Ag}$-Doped $\mathrm{Na}_{1.7} \mathrm{Co}_{2} \mathrm{O}_{4}$ and Its Thermoelectric Properties, J. Alloys Compd., Vol. 467, 444-449, 2009.

[17] P. Liu, G. Chen, Y. Cui, H. Zhang, F. Xiao, L. Wang, H. Nakano. High Temperature Electrical Conductivity and Thermoelectric Power of $\mathrm{Na}_{x} \mathrm{CoO}_{2}$, Solid State Ionics, Vol. 179, 2308-2312, 2008.

[18] N.S. Krasutskaya, A.I. Klyndyuk, L.E. Evseeva, S.A. Tanaeva. Influence of the sodium content on properties of lamellar cobaltite $\mathrm{Na}_{x} \mathrm{CoO}_{2}(0.53 \leq x \leq 0.98)$, Proc. NAS of Belarus, Ser. Chem. Sci., No. 1, 11-15, 2012. [in russian]

[19] A.I. Klyndyuk, N.S. Krasutskaya, E.M. Dyatlova. Effect of Siontering Temperature on the Properties of $\mathrm{Na}_{x} \mathrm{CoO}_{2}$, Proc. Of BSTU, Ser. III, Chem. and Technol. Inorg. Subst., No. XVIII, 99-102, 2010. [in russian]

[20] A.I. Klyndyuk, E.A.Chizhova. Effect of Cation Deficiency on the Structure and Properties of Layered Lanthanum Barium ferrocuprate, Rus. J. of Inorg. Chem., Vol. 53, No. 4, 524-529, 2008.
[21] A.I. Klyndyuk, Ye.A.Chizhova, N.V. Sazanovich, N.S. Krasutskaya. Thermoelectric properties of some perovskite oxides, J. of Thermoelectricity, No. 3, 72-80, 2009.

[22] A.I.Klyndyuk, Ye.A. Chizhova. Thermoelectric properties of the layered oxides $\mathrm{LnBaCu}(\mathrm{Co}) \mathrm{FeO}_{5+\delta}(\mathrm{Ln}=\mathrm{La}, \mathrm{Nd}, \mathrm{Sm}$, Gd), Funct. Mater., Vol. 16, No 1, 17-22, 2009.

[23] A.I. Klyndyuk, I.V. Matsukevich. Synthesis and Properties of $\mathrm{Ca}_{2.8} \mathrm{Ln}_{0.2} \mathrm{Co}_{4} \mathrm{O}_{9+\delta}(\mathrm{Ln}-\mathrm{La}, \mathrm{Nd}, \mathrm{Sm}, \mathrm{Tb}-\mathrm{Er})$ Solid Solutions, Inorg. Mater., Vol. 48, No. 10, 1052-1057, 2012.

[24] T. Kawata, I. Iguchi, T. Itoh, K. Takahata, K. Terasaki. Na-Site Substitution Effects on the Thermoelectric Properties of $\mathrm{NaCo}_{2} \mathrm{O}_{4}$, Phys. Rev. B, Vol. 60, No. 15, 10584 (4 pages), 1999-I.

[25] M. Premila, A. Bharati, N. Gayathri, P. Yasodha, Y. Hariharan, C.S. Sundar. Metal-insulator transition in Ni-doped $\mathrm{Na}_{0.75} \mathrm{CoO}_{2}$ : Insights from infrared studies, Pramana - J. of Physics, Vol. 67, No. 1, 153-162, 2006.

[26] I.V. Matsukevich, A.I. Klyndyuk. Effect of Preparation Method on the Structure and Properties of the Layered Calcium Cobaltate, J. Appl. Chem., Vol. 1, No. 1, 73-84, 2013.

[27] W. Koshibae, K. Tsutsui, S. Maekawa. Thermopower in Cobalt Oxides, Phys. Rev. B, Vol. 62-I, . No. 11, 6869$6872,2000$. 